\title{
INTEGRATING CULTURE INTO EFL TEACHING BEHIND CLASSROOM DOORS: A CASE STUDY OF UPPER SECONDARY TEACHERS IN VIETNAM
}

\author{
Chau Thi Hoang Hoa* ${ }^{* 1}$ Truong Vien ${ }^{2}$ \\ 1. Department of International Collaboration and Project Promotion, Tra Vinh University, \\ No.126, Nguyen Thien Thanh, Ward 5, Tra Vinh, Vietnam \\ 2. University of Foreign Languages, Hue University, \\ 57 Nguyen Khoa Chiem, An Cuu, Hue, Vietnam
}

Received 5 October 2018

Revised 23 January 2019; Accepted 28 January 2019

\begin{abstract}
In the context of globalization, intercultural integration has gained a better position in teaching and learning English in Vietnam, even in general education. In fact, intercultural objectives and intercultural content have been added to the expected curriculum and pilot coursebooks for teaching English in upper secondary education. Prior to the implementation of the new curriculum, it is essential to explore how teachers deal with intercultural content provided in the coursebooks. From the view of intercultural teaching, this study focuses on the positionality of intercultural objectives and intercultural teaching strategies in teachers' practice. Data collected from 101 teachers through questionnaire and six class observations illustrate that (1) teachers did not include intercultural objectives in EFL lessons and (2) they rarely conducted intercultural language activities in their teaching practice. It is recommended that intercultural education needs more attention from educational managers to support the EFL teachers in upper secondary schools to incorporate culture into their teaching more effectively, which contributes to the accomplishment of a reformed English curriculum objective - building comprehensive intercultural competence for the students.
\end{abstract}

Keywords: intercultural competence, intercultural objectives, intercultural teaching, teaching EFL in general education

\section{Introduction}

In regional and global integration, intercultural competence (IC) is essential for global citizens in the 21 st century (Stiftung \& Cariplo, 2008). In response to that trend, the incorporation of teaching cultures into teaching English to enable learners to communicate across linguistic and cultural boundaries has successfully become an increasing trend

\footnotetext{
Corresponding author. Tel.: 84-939290291

Email: cthhoa@tvu.edu.vn
}

(Byram \& Kramsch, 2008). In the same line, Vietnamese language-in-education policy gradually has extended the focus of foreign language teaching and learning from building communicative competence (CC) to the combination of IC and $\mathrm{CC}$, or intercultural communicative competence (ICC) for the students in upper secondary schools.

For the above reason, the role of intercultural education is evidenced with the change of coursebooks and curricular objectives from the current to the expected 
curricula. The representation of culture in the pilot curriculum is more comprehensive and explicit than in the standard one. In fact, Hoang (2011) confirms one of the objectives of the standard coursebooks is to build learners' understanding of cultures of English-speaking countries and Vietnam through the familiarity of cultural input included in English lessons. For the pilot version, Hoang (2016, 2018) believes that it brings more diversity of intercultural content with the extension to other cultures such as Singapore, Malaysia, China, Thailand, South Korea, and Japan to develop students' CC and approach to comprehensive IC. The introduction of a newly-added section - Communication and Culture - is a good example of overt intercultural integration of the pilot coursebooks. Evaluating the diversity of intercultural contents in the pilot coursebooks, Lai (2016) proves that the proportions of home, target, and international cultures in English 10, volume 1, are 51\%, $31 \%$, and $18 \%$ respectively.

Therefore, it is confirmed that the integration of culture into teaching English as a foreign language (EFL) in Vietnam has been recognized from macro level with the evidence of IC objectives in the curriculum and the representation of intercultural content and activities in the pilot coursebooks. However, to enact this reformation comprehensively, EFL teachers should take active roles as the main implementers, who integrate culture into their teaching appropriately to their students and teaching contexts. In defining appropriate strategies for intercultural integration, it is necessary to discuss intercultural teaching approaches with specified principles, strategies, and objectives in the literature and previous studies.

\section{Literature review}

There is a great body of literature in intercultural integration in language teaching in terms of intercultural teaching approaches and IC elements.

\subsection{Intercultural teaching approaches and intercultural objectives}

\subsubsection{Intercultural teaching approaches} and principles

There is no consensus in defining culture because it is defined differently from different fields of study. In language teaching, it should be viewed in relation to language because "culture shapes what we say, when we say it, and how we say it" (Liddicoat, 2002, p.5). Additionally, culture is dynamic and everchanging and so are practices, behaviors, beliefs, and values of cultural groups of people (Browett, 2003; Sewell, 2005).

In the history of culture teaching, culture as practice is originated from dynamic view of culture (Newton, Yates, Shearn, \& Nowitzki, 2010; Ho, 2011). This approach is widely receptive for aiming to develop skills to communicate and behave right in the target language culture, but it is blamed for ignoring the roles of learners' home culture (Crozet, Liddicoat \& Lo Bianco, 1999). Therefore, Crozet et al. (1999) propose intercultural language teaching approach to promote students' acquisition of IC through intercultural language activities, namely exploring cultures and comparing home and target language culture. However, both the culture as practice and the intercultural language teaching approach ignore the interculturality of intercultural communication. Therefore, embracing the ideas practicing culture and acquiring culture of the two mentioned approaches, intercultural (language) teaching aims to build 
leaners' IC though their personal engagement in social intercultural communication in form of intercultural (language) activities (Byram, 2006; Deardorff, 2006; Liddicoat \& Crozet, 1997; Newton et al. 2010; Newton, 2016). On that basis, Liddicoat and Crozet (1997), Newton et al. (2010), and Newton (2016) propose principles for intercultural integration into language teaching, also known as principles for intercultural communicative language teaching (iCLT principles).

In the context of teaching EFL at upper secondary level in Vietnam, the principles could be summarized and applied as follows. First, the iCLT principles emphasize the balance and integral integration of language and culture. Relating the position of culture in language lessons, the representation of culture could be either implicit of explicit. According to Hatoss (2004), the distinction between implicit and explicit intercultural integration is attributed to the frequency of cultural input and the depth of activities to exploit it. To clarify, implicit intercultural incorporation involves the introduction of cultural input in language skill lessons while explicit intercultural integration invokes learners' reflections on cultural input and their engagement in intercultural language activities. In this way, IC and CC are fostered through language and culture learning and acquiring. Secondly, the diversity of intercultural input is encouraged by iCLT because fostering IC to enable learners to communicate in intercultural contexts is more important than building CC like that of nativespeakers. Obviously, iCLT approves a shift of language teaching objective, from IC to ICC. It is worth noticing that building ICC entails learners' engagement in social intercultural interactions, so the nature of classroom activities should be altered from languagefocused to language and culture-focused.
In sum, embracing the iCLT principles, the explicit integration of culture necessitates the active implementation of teachers in which they exploit the provided language and culture input through intercultural language activities to accomplish IC or ICC objectives.

\subsubsection{Defining IC models and IC} objectives

As far as intercultural objectives and intercultural teaching activities are concerned, IC and ICC should be defined. In the literature, two noticeable models of IC have been introduced by Byram (1997) and Fantini (2006).

Byram (1997) develops an ICC model constituted from five interrelated components, known as the five savoirs: (1) savoir être attitude, (2) savoirs - knowledge, (3) savoir comprendre - skills to interpret and relate, (4) savoir apprendre/faire - skills to discover and interact, and (5) savoir s'engager - critical cultural awareness. Being widely accepted, this model had some critics. To begin, it could not convey the developmental progress of and interrelatedness among the competences, as well as the language and culture relationship (Liddicoat \& Scarino, 2010; Matsuo, 2015). More importantly, Byram's (1997) perspective on culture was claimed for emphasising on national culture (Matsuo, 2015).

Fantini(2006) proposes ICCmodel including multiple constituents, of which language competence and its four IC dimensions are most noticeable. The four dimensions - knowledge, (positive) attitudes, skills, and awareness are arranged in a spiral and dynamic circle. Intercultural knowledge refers to understanding of other cultures; intercultural skills referring to the capacity to engage in intercultural contexts; intercultural attitudes referring to the openness to the differences; and intercultural awareness referring to the feelings about the self in relation to the others (Fantini, 2006). Compared 
to Byram's (1997), the clear-cut separation of language and culture competence and integratedness among the dimensions provokes an ease of application in defining the levels of IC and $\mathrm{CC}$ in EFL teaching.

As advocates of analytical measurement of the IC, Deardorff (2006), Ho (2011) and Tran (2015) adopted the four elements of IC, suggested by Fantini (2006) for graded and separated IC objectives in EFL lessons. Depending on the context and learnerdifference, this research does not take awareness, the most advanced element, into account because building intercultural awareness requires the learners' critical reflection from engagement in actual intercultural interactions (Ho, 2011; Liddicoat et al., 2003), which is not quite common and accessible in EFL teaching at upper secondary level in Vietnam. In sum, the three elements of IC: intercultural knowledge, intercultural attitudes, and intercultural skills are considered three levels of IC objectives that regulate the intercultural language activities in this study.

\subsection{Intercultural strategies in previous studies}

A number of related studies in Europe (Gönen \& Sağlam, 2012; Sercu, Bandura, Castro, Davcheva, Laskaridou \& Lundgren, 2005; Sercu, María García, \& Prieto, 2005) and in Vietnam (Chau \& Truong, 2018; Ho, 2011; Nguyen, 2013; Tran \& Dang, 2014) are found relevant to this study as they investigated teachers' practices of intercultural integration in language teaching.

Exploring how English teachers in seven European countries dealt with culture, Sercu et al. (2005a) found that they shared common practices. First, culture teaching in Europe was more teacher-centred than studentcentred. Activities developing students' intercultural knowledge and attitudes were more prominent than intercultural skills. In another study, Sercu et al. (2005b) expected teachers to scaffold students by engaging them in multi-levels of input familiarity and meaning construction activities through social interactions. However, it was found that most of the cultural content was traced back to the coursebooks and high-ranking domains of culture such as values and beliefs were almost avoided. Cultural transmission was dominant while independent exploration and critical reflections of culture were rare. Similar to Sercu et al. (2005a) and Sercu et al. (2005b), Gönen and Sağlam (2012) found that English teachers in Turkey prioritized teaching intercultural knowledge to teaching intercultural attitudes and skills.

Four studies in Vietnam, conducted by Chau and Truong (2018), Ho (2011), Nguyen (2013), and Tran and Dang (2014) exploring teachers' practices of intercultural teaching, had rather similar findings. First, Chau and Truong (2018), Ho (2011), Nguyen (2013), Tran and Dang (2014) confirmed that transmitting intercultural knowledge from their coursebooks was the most common activity. Chau and Truong (2018) and Ho (2011) explained that teachers' intercultural integration was topic-dependent and peripheral due to their considerable concerns of language objectives. Chau and Truong (2018) and Nguyen (2013) assumed that teachers granted implicit and peripheral status to intercultural teaching and mostly relied on the cultural content in teaching materials. Tran and Dang (2014) proved that both Vietnamese teachers of English (VTEs) and native English teachers (NETs) were inclined to activities to develop learners' intercultural knowledge, but the strategies utilized were relatively different. While VTEs incorporated culture in EFL skill lessons thanks to artefacts and cultural informants, NETs told students about their native cultures. 
As previously mentioned, teachers considered culture an integral and implicit part of language teaching and managed to conduct intercultural language activities to support students' language learning. In the transitional period of educational reformation to enable the young Vietnamese in globalization, it is necessary to investigate teachers' intercultural integrating practice to build learners' IC and CC through intercultural language activities. That issue is expressed in the following research question:

How and what do EFL teachers in upper secondary schools do to integrate culture into their teaching to build students' IC?

\section{Methodology}

In order to support the evidences to answer the research question, this research engages 101 EFL teachers for their responses to the questionnaire and six teachers for classroom observations. Details about the participants and instruments are discussed in this section.

\subsection{Research participants}

This research was conducted in the second semester of the academic year 2017-2018, when the two versions of English coursebooks, the standard and pilot ones, had been implemented concurrently. One hundred and one out of 190 EFL teachers in the upper secondary schools in a Southern province of Vietnam voluntarily joined the research by giving their responses to questionnaires. Of them, 28 teachers have used both pilot and standard coursebooks and 73 having used the standard version only.

\subsection{Research instruments}

The research combines qualitative and quantitative data from questionnaires with an open-ended question and class observations. The quantitative data were collected and analysed statistically based on responses from 101 EFL participating teachers. The openended question was used additionally with the questionnaire to explore other intercultural teaching practices of the participating teachers. Classroom observations were done in six classes of Grades 10 and 11 using both standard and pilot coursebooks to provide information about teachers' actual teaching practices.

The questionnaire with the open-ended question

The questionnaire, adopted from Chau and Truong (2008) and Sercu et al. (2005), comprised 16 items (See Appendix 1). They were organized in a five-point Likertscale questionnaire from never to always for the frequency of intercultural language activities conducted in class. The activities are categorized into the degree of studentcenteredness and relevant potential IC objectives, namely developing intercultural knowledge, fostering intercultural attitudes (item B5, B10, B11, B12, B13, B14, and $\mathrm{B} 15$ ), and building intercultural skills (item B8, B9, and B16). Of them, the first one, developing intercultural knowledge was further divided into teaching intercultural knowledge (item B1, B2, and B3) and having students explore cultures (item B4, B6, and B7). Other practices of the teachers were collected through the open-ended question at the end of the questionnaire. Gaining accepted reliability in the pilot stage $(\alpha=.775)$, the used questionnaire achieved satisfactory level of coefficient reliability ( $\alpha=.886)$.

\section{The observation}

Six class observations were conducted for teachers' actual practices to cross-check with the practices self-reported through the questionnaire. Information about the observations is presented in Table 1. 
Table 1. Information of six class observations

\begin{tabular}{|c|c|c|c|}
\hline Observation & Coursebook version & Grade & Lessons \\
\hline 1. & Pilot & Unit 2, Grade 10 & Communication and Culture \\
\hline 2. & Pilot & Unit 5, Grade 10 & Communication and Culture \\
\hline 3. & Pilot & Unit 2, Grade 11 & Communication and Culture \\
\hline 4. & Pilot & Unit 3, Grade 11 & Communication and Culture \\
\hline 5. & Standard & Unit 8, Grade 10 & Skill lesson - Reading \\
\hline 6. & Standard & Unit 8, Grade 11 & Skill lesson - Reading \\
\hline
\end{tabular}

The same observation scheme was used for all observations. It focused on how the teachers exploited language and cultural input in their lessons. In addition, students' engagement, nature of cultural input, and balance of language and culture were recorded to more comprehensively describe progress of the lessons.

\subsection{Data collection and analysis}

Data collected from responses of 101 teachers were subjected to descriptive analysis for mean score of each item, cluster, and average mean scores. Also, an independent sample
T-test was used to measure the level differences between mean scores of the two groups of teachers, who had and had not used the pilot coursebooks. Qualitative data collected from the open-ended question and observation schemes were classified and coded according to the explicity of intercultural integration activities and their potential levels IC objectives.

\section{Findings}

Descriptive statistics of teachers' intercultural teaching practices is reported in Table 2.

Table 2. Mean scores of intercultural teaching activities

\begin{tabular}{|c|c|c|c|c|}
\hline Items & $\begin{array}{l}\text { Total } \\
\text { mean }\end{array}$ & $\begin{array}{c}\text { Stand. } \\
\text { mean }\end{array}$ & $\begin{array}{l}\text { Pilot } \\
\text { mean }\end{array}$ & $\begin{array}{l}\text { Sig. }(*) \\
\text { (2-tailed) }\end{array}$ \\
\hline Cluster 1: Teaching intercultural knowledge & 3.60 & 3.59 & 3.60 & .950 \\
\hline $\begin{array}{l}\text { B1. I relate the cultural contents to what I have learned and experienced } \\
\text { about the foreign cultures or countries. }\end{array}$ & 3.48 & 3.44 & 3.57 & .315 \\
\hline $\begin{array}{l}\text { B2. I provide my students with appropriate language used in different } \\
\text { communicative situations. }\end{array}$ & 3.59 & 3.62 & 3.54 & .513 \\
\hline $\begin{array}{l}\text { B3. I help my students to learn about how to do things and behave in different } \\
\text { social interactions. }\end{array}$ & 3.72 & 3.71 & 3.75 & .752 \\
\hline Cluster 2: Having students explore cultures & 2.85 & 2.81 & 2.94 & .305 \\
\hline B4. I ask my students to share aspects of their own culture in English. & 3.27 & 3.25 & 3.32 & .596 \\
\hline $\begin{array}{l}\text { B6. I ask my students to do kinds of projects to introduce their own or local } \\
\text { culture to the foreigners. }\end{array}$ & 2.58 & 2.51 & 2.79 & .113 \\
\hline $\begin{array}{l}\text { B7. I ask my students to explore an aspect of the foreign culture and present it } \\
\text { to their friends. }\end{array}$ & 2.68 & 2.67 & 2.71 & .789 \\
\hline Cluster 3: Developing positive intercultural attitudes & 2.75 & 2.75 & 2.76 & .914 \\
\hline B5. I mention the relativity of prejudices and risks of generalization. & 3.08 & 3.12 & 2.96 & .436 \\
\hline
\end{tabular}




\begin{tabular}{|c|c|c|c|c|}
\hline Items & $\begin{array}{l}\text { Total } \\
\text { mean }\end{array}$ & $\begin{array}{l}\text { Stand. } \\
\text { mean }\end{array}$ & $\begin{array}{l}\text { Pilot } \\
\text { mean }\end{array}$ & $\begin{array}{l}\text { Sig. }(*) \\
\text { (2-tailed) }\end{array}$ \\
\hline $\begin{array}{l}\text { B10. I decorate my classroom with pictures, ornaments, and so on to illustrate } \\
\text { aspects of the foreign culture. }\end{array}$ & 1.88 & 1.85 & 1.96 & .562 \\
\hline $\begin{array}{l}\text { B11. I use videos, CD-ROMs or the Internet to illustrate aspects of the foreign } \\
\text { culture like songs, films, fashions, festivals and so on. }\end{array}$ & 3.17 & 3.12 & 3.29 & .372 \\
\hline B12. I also teach the similarities between the home and foreign cultures. & 3.36 & 3.34 & 3.39 & .762 \\
\hline $\begin{array}{l}\text { B13. I encourage the students to explore the causes of differences the home } \\
\text { and foreign cultures. }\end{array}$ & 2.83 & 2.85 & 2.79 & .731 \\
\hline $\begin{array}{l}\text { B14. I have my students approach to diverse cultural facts and notions to } \\
\text { create positive perspectives towards the differences. }\end{array}$ & 2.52 & 2.52 & 2.50 & .912 \\
\hline $\begin{array}{l}\text { B15. I get my students to evaluate their home and foreign culture from } \\
\text { different views. }\end{array}$ & 2.42 & 2.41 & 2.43 & .926 \\
\hline Cluster 4: Having students practise language and culture in different settings & 1.87 & 1.84 & 1.96 & .382 \\
\hline $\begin{array}{l}\text { B8. I organize some simulated intercultural communicative activities like } \\
\text { celebrating cultural events, role plays, solving cultural conflicts, and so on for } \\
\text { students to practise linguistic and intercultural skills. }\end{array}$ & 2.42 & 2.43 & 2.39 & .864 \\
\hline B9. I invite a person originating from the foreign countries to my class. & 1.57 & 1.52 & 1.71 & .281 \\
\hline $\begin{array}{l}\text { B16. I engage students into a chat group with foreigners to share their cultural } \\
\text { knowledge and experience. }\end{array}$ & 1.62 & 1.56 & 1.79 & .208 \\
\hline
\end{tabular}

(*) The mean difference is significant at the 0.05 level.

For the whole group of participating teachers, average mean scores of the four clusters (M1, M2, M3, and M4) display a downward trend from teaching intercultural knowledge $(\mathrm{M} 1=3.60)$ to developing intercultural attitudes $(\mathrm{M} 3=2.75)$ and skills (M4 =1.87), from conducting teacher-centred activities to student-centred ones (M1 $=3.60$ and $\mathrm{M} 2=2.85$ ).

Noticeably, of the four clusters, the levels of mean differences between two groups of teachers were not significant $(\mathrm{p}=.950$, $.305, .914$, and $.382,>.05)$. Statistically, it is concluded that teachers using different coursebooks demonstrated rather similar practice of intercultural teaching. However, the number of participating teachers using the pilot coursebooks $(\mathrm{N}=28)$ was small and much lower than that of the standard coursebooks $(\mathrm{N}=73)$, the results of inferential statistics should be backed up with mathematical analysis. Mathematically, comparing means of the four clusters across the groups, it is shown that teachers who used the standard (stand.) coursebooks conducted intercultural language activities less often than the other group (M1 of stand. and pilot $=3.59$ versus 3.60 , M2 of stand. and pilot $=2.81$ versus $2.94, \mathrm{M} 3$ of stand. and pilot $=2.75$ versus 2.76 , and M4 of stand. and pilot $=1.84$ versus 1.96 ).

In Table 2, in terms of addressing intercultural knowledge, teacherfronted activities were more common. Noteworthily, activities to deal with culture in communication and culture in language $(\mathrm{M} \mathrm{B} 3=3.72$ and $\mathrm{M} \mathrm{B} 2=3.59$ respectively $)$ were more frequent than adding related cultural content to language lessons (M B1 = 3.48). However, the opposite was proven in the observations. While adding intercultural knowledge to facilitate language learning was seen in Observations 1 and 2 and teaching structures and expressions as language input to enable students' interactions was conducted in Observation 4, no activity to instruct students' conducts and behaviors was found. For example, the teachers in Observations 1 and 2 gave more examples about the balance 
of yin and yang in Vietnamese eating habits and many facts about the King of Thailand to kindle students' interests for reading. In Observation 4 students were provided with appropriate language to compare ways of bringing up children in Viet Nam and in the USA. The occurrence of this type of activities was also of high frequency in teachers' reports.

Of student-centred activities, presenting and sharing intercultural knowledge and experiences ( $\mathrm{M} \mathrm{B} 4=3.27$ ) are more common than participating in projects $(\mathrm{M} \mathrm{B} 6=2.58)$ and exploring cultures $(\mathrm{M} \mathrm{B7}=2.68)$. Of the three activities, only presenting and sharing activity was conducted to get students to raise their personal and cultural voice. Particularly, teachers using the pilot coursebooks conducted project activities more often (M B6 pilot and stand. $=2.79$ versus 2.52 ). Similarly, studentcentred intercultural activities were observed in classes using different coursebooks, but they happened more frequently in classes using the pilot coursebooks. They were found in Observations 1, 3, 4, and 6, in which the students could use language productively to share about traditional health practices, Tet holidays, family education, and dating from their own personal and local culture perspectives. Similar activities were not found in Observations 2 and 5 because they were not presented in the coursebooks.

Among the activities to develop students' attitudes, three most frequent activities were comparing cultures (M B12 = 3.36), using audio-visual aids to bring culture diversity to the students $(\mathrm{M} \mathrm{B11}=3.17)$, and mentioning relativity of prejudices (M B5 $=3.08$ ). Other advanced activities (such as exploring the roots of differences, evaluating the differences, and forming positive perspectives towards the differences and diversity) rarely happened in the classes $(\mathrm{M} \mathrm{B13}=2.83, \mathrm{M} \mathrm{B} 15=2.42$, and $\mathrm{M} \mathrm{B} 14=2.52$ respectively). A simple activity, displaying artefacts, almost never took place (M B10 = 1.88).

Of the three activities with positive mean scores (expressed in item B12, B11, and B5), only comparing culture was conducted. It was commonly seen in Communication and Culture lessons of Observations 1 and 4, in which the students were asked to compare health practices between Vietnamese and Indonesian cultures and child rearing between Vietnamese and American cultures. This activity engaged students in authentic interactions by presenting their own reflections and comparisons based on their prior knowledge and cultural diversity. In the two lessons, the teachers did not exaggerate the differences or mentioned the relativity of stereotyping in the comparison.

Finally, the three last activities to engage students into real or simulated intercultural communication to develop intercultural skills were never or rarely conducted. Simulated intercultural activities (e.g., celebrating cultural events, role plays, solving cultural conflicts) were rare $(\mathrm{M} \mathrm{B} 8=2.42)$ while activities engaging students into actual interactions by inviting guest speakers and joining chat groups were often ignored (M $\mathrm{B} 9=1.57, \mathrm{M} \mathrm{B} 16=1.62)$. Creating simulated or actual intercultural communication was limited but teachers using the pilot coursebooks managed to deliver activities for students practicing intercultural skills more often (M4 of pilot and stand. $=1.96$ versus 1.84). It was interesting that the teachers using the pilot coursebooks less favoured simulated intercultural communication activities (M B8 of pilot and stand. $=2.39$ versus 2.43 ) while the teachers of the other group were less interested in the actual ones (M B9 and B16 of stand. and pilot $=1.52$ versus $1.71,1.56$ versus 1.79). Scarcity of these types of activities was also proven in the observations. In fact, none 
of additional activities creating opportunities for students to practice intercultural skills were found. Remarkably, the existence of these activities was mentioned in open-ended question reports. As informed, intercultural activities, namely cultural quizzes, guessing the pictures, role-play to solve cultural conflicts, and drama were conducted to make opportunities for students to practice and build their IC and CC.

Formost of the part, findings of this research echo those of the others in Europe and Vietnam in that intercultural teaching was inferior to language teaching and equated with teaching intercultural knowledge. However, conducted in the context of general education prior to the educational reformation, the findings have obtained its own values in the field. First, what the participating teachers did by their own attempts to integrate culture was adding intercultural facts related to cultural themes in language skill lessons. The other activities, which were comparing cultures, talking about intercultural issues, and doing projects were coursebook-prescribed. Secondly, though teachers using different coursebooks shared similar practice of intercultural integration, the representation of intercultural language activities was more apparent in the classes using the pilot coursebooks. Thirdly, there is a gap between IC objectivity prescribed in the master EFL curriculum and teachers' actual implementation. Specifically, while intercultural content and activities are considered a new focus in the pilot coursebooks, teachers have not relevantly exploited them explicitly and effectively. Therefore, the findings signify that the gap between the expected objectives and actual practices should be filled with the improvement of teachers' practices.

\section{Discussion and implications}

In line with the studies of Chau and Truong (2018), Gönen and Sağlam (2012), Ho (2011), Nguyen (2013), Sercu et al. (2005), Sercu et al. (2005b), Tran and Dang (2015), this research confirmed that intercultural integration in upper secondary schools was not properly treated in terms of intercultural objectives and intercultural teaching strategies.

First, though the position of IC in EFL teaching programs has been recognized in pilot curriculum, IC objectives were not specified explicitly in teachers' lessons. For example, even for the Communication and Culture lessons, the teachers (in Observations $1,2,3$, and 4) were unaware of intercultural objectives. The inclusion of educational objectives enables language teaching to fulfil its instrumental and educational purposes (Byram, 2008). As observed and noticed, intercultural objectives were sometimes coined in more general terms - educational or moral objectives. Whatever they were called, IC objectives should be specified with the graded levels of IC and the focus of cultural aspects to regulate the intercultural language activities in EFL lessons.

Secondly, in alignment with Chau and Truong (2018), Gönen and Sağlam (2012), Ho (2011), Nguyen (2013), Sercu et al. (2005b), and Tran and Dang (2015), the participating teachers' intercultural integration was teachercentred, knowledge-based, coursebookdependent, and peripheral. As reported, what the teachers did to deal with intercultural integration were following the coursebooks and adding intercultural facts from their knowledge and experiences to facilitate language teaching. In most Communication and Culture lessons (Observations 1, 2, 3, and 4), the implementation of intercultural activities was traced back to the coursebooks. 
Teachers had no adaption to invoke genuine interaction and critical interaction among the students. Giving reasons for that, Sercu et al. (2005b) assumed that teachers observed the language input and activities in coursebooks because it was easier and safer.

However, it is noteworthy considering that teachers using the pilot coursebooks were in favour of activities which activated students' centeredness and targeted advanced IC levels. Roughly compared means of the four clusters between the two groups of teachers, teachers using the pilot coursebooks surpassed the other group in terms of delivering activities having students explore cultures (Cluster 2) and practise language and culture in different settings (Cluster 4). Higher mean scores of the two clusters prove a consistent appreciation of teachers using the pilot coursebooks for students' independence and active engagement in intercultural activities. More importantly, the higher frequency of activities exploring culture delivered by the teachers using the pilot coursebooks was explained by the representation of intercultural content and activities in the coursebooks. In fact, exploring and presenting cultural viewpoints were common in the pilot coursebooks; even more, doing project was a recognized and separate section - Project - in every unit of this coursebook version.

To bridge the gap between current practice of teachers and the effective implementation of intercultural integration into EFL teaching as a requirement of educational reformation, explicit intercultural integration guided by iCLT principles should be considered besides the change of curriculum objectives and coursebooks. Stated differently, teachers should improve their intercultural teaching practice which entails the adaption of prescribed activities in the coursebooks to invoke genuine intercultural interactions among students and more critical reflection of intercultural contents from the coursebooks against the reality that they have experienced as social and cultural informants.

The implications are not likely to be feasible for the teachers without supports and guidance from educational management. Actually, teachers could not improve the intercultural integration practices due to the overwhelming focus on teaching EFL for testing and overcrowded curriculum (Chau \& Truong, 2018). Besides, teachers' training on IC and intercultural teaching pedagogy was absent from pre-service and in-service teacher education (Nguyen, 2013). Without comprehensive pedagogical apprehension, teachers could make intercultural integration dissociating and superficial (Sercu et al., 2005). Hence, teachers should be trained on the positionality and teaching pedagogy of intercultural integration. Without official guidance and proper training, teachers were not flexible enough to implement intercultural integration.

\section{Limitation and conclusion}

Aiming to explore the status of intercultural integration in EFL teaching in upper secondary schools, this research manages to obtain data from teacher questionnaire and observations. Due to the inefficient amount of data collected from quantitative data, the actual practices of intercultural teaching were not a comprehensive representation of other EFL classes. Moreover, intercultural objectives were not presented in teachers' lesson plans or not obvious in their EFL lessons. The finding was still superficial, so the objectivity of IC should receive further and deeper investigation from teachers' perceptions through in-depth interview or other instruments.

In conclusion, prior to the reformation in 
general education, EFL teaching is subjected to a change with comprehensive inclusion of IC objectives and intercultural content in the curriculum. It is proven that intercultural integration has been recognized from macro level but not yet properly implemented in teaching practice due to the domination of intercultural knowledge transmission and rigidity of teachers' implementation. Since intercultural teaching aims to develop IC which requires learners' active engagement in social intercultural interactions, the teachers should "interculturalize" the coursebook activities to facilitate students to build their IC. Therefore, to enhance the effects of intercultural education, teachers should be encouraged and enabled to improve their intercultural teaching practices through more official guidance in lesson planning and implementing strategies.

\section{References}

Browett, J. (2003). Culture: Are we speaking the same language?. Babel, 38(2), 18-38.

Byram, K. \& Kramsch, C. (2008). Why is it difficult to teach language as culture? The German Quarterly, 81(1), 20-34.

Byram, M. (1988). Foreign language education and cultural studies. Language, Culture, and Curriculum, 1(1), 15-31.

Byram, M. (1997). Teaching and assessing intercultural communicative competence. Clevedon, UK: Multilingual Matters.

Byram, M. (2006). Language teaching for intercultural citizenship. Keynote address. Paper presented at the NZALT Conference, University of Auckland, 2-5.

Chau, T. H. H, Truong, V. (2018). Developing intercultural competence for upper secondary students: Perspectives and practice. Kỷ yếu Hội thảo Quốc gia "Nghiên cứu Liên ngành về Ngôn ngũ và Giảng dạy Ngôn ngũ lần thứ III”, 227-239.

Crozet, C. Liddicoat, A. J. and Lo Bianco, J. (1999). Intercultural competence: From language policy to language education. Lo Bianco, J., Liddicoat A. J., and Crozet C. (eds), Striving for the Third Place: Intercultural Competence Through Language Education. Canberra: Language Australia.

Deardorff, D. K. (2006). The Identification and assessment of intercultural competence as a student outcome of internationalization. Journal of Studies in International Education, 10(3), 241-266.

Fantini, A. E. (2006). Exploring and assessing intercultural competence. World Learning Publications. Retrieved from http://www.sit.edu/ publications/docs/feil_research_report.pdf

Gönen, S., Sağlam, S. (2012). Teaching culture in the FL classroom: Teachers' perspectives. International Journal of Global Education, 1(3).

Hatoss, A. (2004). A model for evaluating textbooks. Babel, 39(2), 25-32.

Ho, S. T. K. (2011). An investigation of intercultural teaching and learning in tertiary EFL classrooms in Vietnam (Doctoral dissertation, Victoria University of Wellington, Wellington, New Zealand).

Hoang V. V. (2011). The role of textbooks in the implementation of the national project "Teaching and learning foreign languages in the national education system, period 2008-2020". Proceedings of the International Conference on Textbooks for the 21 th Century.

Hoang, V. V. (2016). Renovation in curriculum design and textbook development: an effective solution to improving the quality of English teaching in Vietnamese schools in the context of integration and globalization. VNU Journal of Science: Education Research, 32(4), 9-20. Retrieved from https://js.vnu. edu.vn/ER/article/view/3845/3576

Hoang, V. V. (2018). MOET's three pilot English language communicational curricula for schools in Vietnam: rationale, design and implementation. VNU Journal of Foreign Studies, 34(2). Retrieved from http:/www.vjol.info/index.php/NCNN/article/ viewFile/35643/29135

Lai, T. T. V. (2016). An evaluation of textbook English 10 - Volume 1 (experimental program) developed by Vietnamese Ministry of Education and training as seen from intercutural communicative EFL approach. Proceedings of National Conference 2016 "Nghiên cứu và giảng dạy ngoại ngũu, ngôn ngũu, và quốc tế học tại Việt Nam”, 407-417.

Liddicoat, A. J. and Scarino, A. (2010). Eliciting the intercultural in foreign language education, in Testing the Untestable in Foreign Language Education (eds A. Paran and L. Sercu), Multilingual Matters, Clevedon, pp. 52-73.

Liddicoat, A. J., Crozet, C. (1997). Teaching culture as an integrated part of language teaching: An introduction. Australian Review of Applied Linguistics, Series $S$.

Liddicoat, A. J., Papademetre, L., Scarino, A., Kohler, M. (2003). Report on intercultural language learning. Canberra, ACT: Commonwealth of Australia.

Liddicoat, A.J. (2002). Static and dynamic views of culture and intercultural language acquisition. Babel, 36(3), 4-11.

Matsuo, C. (2015). A Dialogic critique of Michael 
Byram's Intercultural Communicative Competence Model: Proposal for a dialogic pedagogy. In N. Tomimori (Ed.), Comprehensive study on language education methods and cross-linguistic proficiency evaluation methods for Asian languages: Final report 2014. (Grants-in-Aid for Scientific Research (B), Japan Society for the Promotion of Science), (pp.3-22). Tokyo: Tokyo University of Foreign Studies.

Newton, J. (2016). Cultivating intercultural competence in tertiary EFL programs. Crossing Borders in Language Teaching and Business Communication: Proceedings of the 11th ELT conference at AE CYUT. (1-22). Chaoyang University of Technology, Chaoyang, Taiwan.

Newton, J., Yates, E., Shearn, S., Nowitzki, W. (2010). Intercultural communicative language teaching: Implications for effective teaching and learning. Report to the Ministry of Education, New Zealand. Nguyen, T. L. (2013). Integrating culture into Vietnamese University EFL Teaching: A critical ethnography study (Doctoral dissertation, Auckland University of Technology, New Zealand).
Sercu, E. Bandura, P. Castro, L. Davcheva, C. Laskaridou, U. Lundgren, G. M. del Carmen Méndes, P. Ryan (2005a). Foreign language teachers and intercultural competence. An international investigation. Clevedon, UK: Multilingual Matters. http://dx.doi. org/10.1080/14675980500502321.

Sercu, L., Garcia, M. d. C. M., Prieto, P. (2005b). Culture learning from a constructivist perspective. An investigation of Spanish foreign language teachers' views. Language and Education, 19(6), 483-495.

Sewell, W, H. (2005) Logics of history: Social theory and social transformation. Chicago, IL: University of Chicago Press.

Stiftung, B. \& Cariplo, F. (2008). Intercultural competence - The key competence in the 21st century. Retrieved from www.bertelsmannstiftung. de/fileadmin/files/BSt/Presse/Import

Tran, T. Q., Dang, V. H. (2014). Culture teaching in English language teaching: Teachers' beliefs and their practices. Korea TESOL Journal, 11(1), 207223.

\title{
THỰC TIỄN LỒNG GHÉP VĂN HÓA VÀO GIẢNG DẠY TIẾNG ANH: TRƯỜNG HỢP CỦA GIÁO VIÊN TRUNG HỌC PHỔ THÔNG Ở' VIỆT NAM
}

\author{
Châu Thị Hoàng Hoa ${ }^{1}$, Trương Viên ${ }^{2}$ \\ 1. Phòng Hợp tác Quốc tế và Xúc tiến Dự án, Trương Đại học Trà Vinh, \\ Số 126 Nguyễn Thiện Thành, Phường 5, Trà Vinh, Việt Nam \\ 2. Trường Đại học Ngoại ngũ, Đại học Huế, 57 Nguyễn Khoa Chiêm, An Cựu, Huế, Việt Nam
}

Tóm tắt: Trong bối cảnh toàn cầu hóa, việc lồng ghép văn hóa vào giảng dạy tiếng Anh ở Việt Nam có vị thế ngày càng lớn ngay cả đối với bậc giáo dục phổ thông. Thật ra, mục tiêu và nội dung liên văn hóa đã được giới thiệu trong chương trình tiếng Anh thí điểm ở trung học phổ thông. Trước thềm đổi mới chương trình, việc nghiên cứu thực tế lồng ghép liên văn hóa là cần thiết. Trên lập trường giảng dạy liên văn hóa, nghiên cứu này tập trung vào hai vấn đề: thực hiện mục tiêu liên văn hóa và chiến lược dạy liên văn hóa. Thông tin thu thập từ 101 giáo viên tiếng Anh qua bảng hỏi và dự giờ chứng minh rằng giáo viên (1) không đề cập đến mục tiêu liên văn hóa trong giáo án; và (2) hiếm khi tổ chức các hoạt động xây dựng năng lực giao tiếp liên văn hóa cho học sinh trong lớp học. Bài viết cho rằng cần có sự quan tâm hơn nữa từ những nhà quản lý giáo dục nhằm hỗ trợ giáo viên phổ thông trung học thực hiện việc tích hợp văn hóa trong giảng dạy tiếng Anh một cách hiệu quả, từ đó, góp phần đạt được mục tiêu chương trình tiếng Anh cải cách - hướng đến xây dựng năng lực liên văn hóa cho học sinh.

Từ khóa: năng lực liên văn hóa, mục tiêu liên văn hóa, dạy liên văn hóa, dạy tiếng Anh ở phổ thông 


\section{APPENDIX 1: TEACHER QUESTIONNAIRE}

How often do you conduct the below activities to integrate culture into your teaching practices? Write the number of your choice in the right column of the table below.

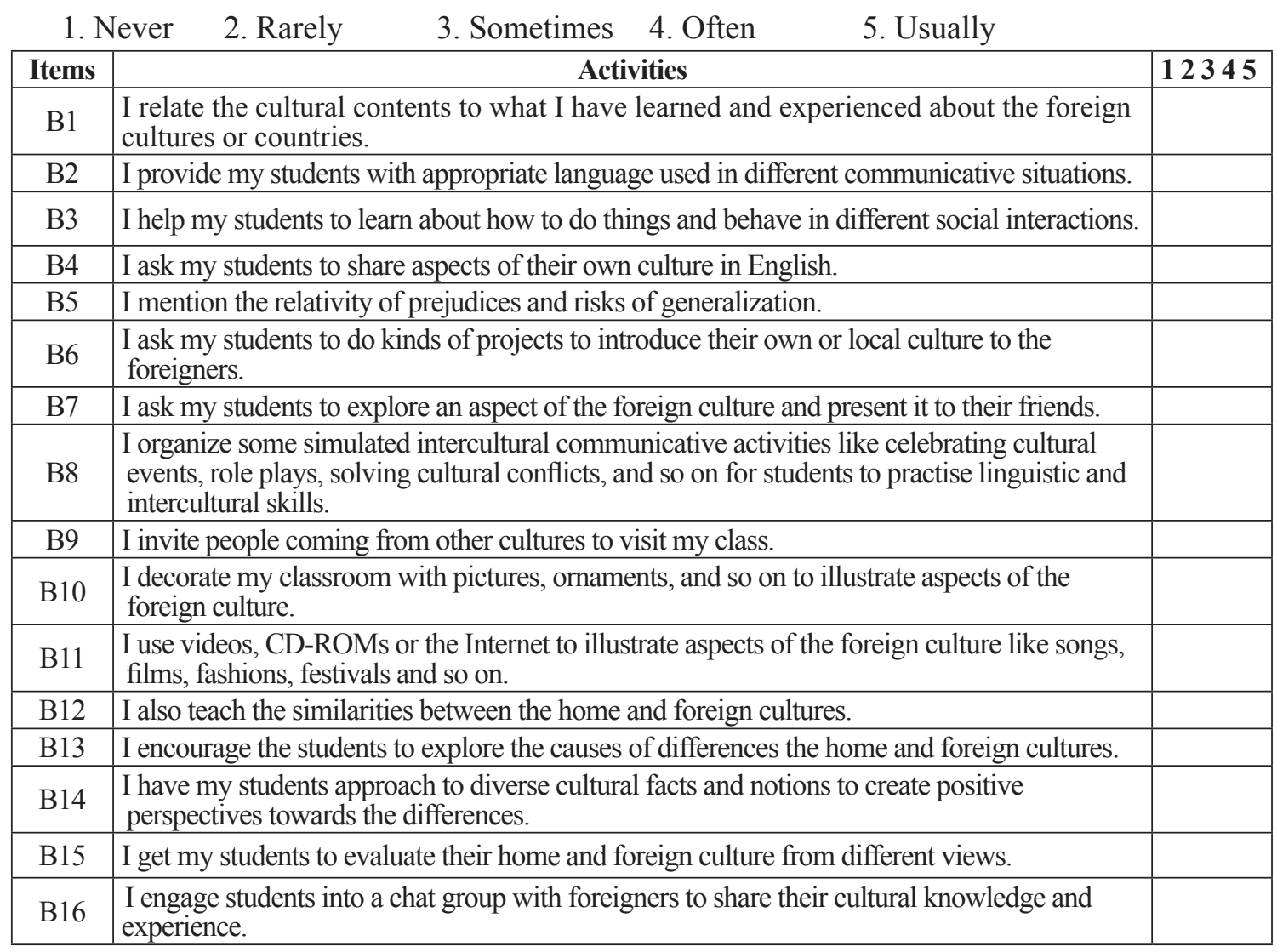

2. What are other activities which you conduct to integrate culture in your teaching? 